\title{
CURRENT STATE AND PROSPECTS FOR USE OF LAND RESOURCES IN THE REPUBLIC OF BELARUS
}

\author{
Kolmykov Andrey, Avdeev Alexey \\ Belarusian State Agricultural Academy, Republic of Belarus
}

\begin{abstract}
All land of the Republic of Belarus can be classified by categories ( 7 categories), types of lands (14 types), land users, forms of ownership and types of rights to land plots.

The total area of land in the Republic of Belarus is 20760 thousand hectares, including agricultural land occupies 9103.0 thousand hectares $(43.8 \%)$ of the total area of the republic; settlements, horticultural associations, dacha cooperatives - 849.0 thousand hectares $(4.1 \%)$; industry, transport, communications, energy, defense and other purposes - 622.2 thousand hectares (3.0\%); environmental, health, recreational, historical and cultural purposes 868.7 thousand hectares $(4.2 \%)$; forest fund - 8656.4 thousand hectares $(41.7 \%)$; water fund - 37.3 thousand hectares $(0.2 \%)$; reserve land - 623.4 thousand hectares $(3.0 \%)$.

The basis of the land resources used in the agro-industrial complex of the republic is arable land, meadows and land under permanent crops, which in general occupy 8387.1 thousand hectares, or $40.4 \%$ of the total area of land. The state owns 20683.6 thousand hectares $(99.63 \%)$ of land, private property -76.4 thousand hectares $(0.37 \%)$ of the total area of all lands of the republic.

In terms of environmental stability, the territory of the republic belongs to medium-stable territories, the coefficient of environmental stability is 0.63 , and in terms of the degree of anthropogenic load - to territories with a relatively low anthropogenic load, the coefficient of anthropogenic load is 2.79 .
\end{abstract}

Key words: land management, land resources, ecological state, land optimization.

\section{Introduction}

Currently, in the Republic of Belarus, as well as throughout the world, there is an acute problem of environmental degradation and degradation of natural systems. Against this background, there is a significant increase in the growth of agricultural production, including environmentally friendly, which causes the need for intensive use of land resources, revision of agricultural production technologies, as well as the farming system. At the same time, the widespread application of the principles of intensive farming, aimed at increasing the area of productive arable and meadow lands, often negatively affects the state of ecosystems, gradually destroying them, this fact is aggravated by the increased anthropogenic impact.

The above reasons lead to the ecologically irrational use of land resources, which, in turn, leads to the loss of sufficiently large productive areas due to a decrease in their natural fertility. The most significant threat is posed by the excessively high use of synthetic fertilizers and pesticides, depletion and salinization of soils, drainage of swamps, and land degradation.

A number of works by European scientists are devoted to the development of land relations, the ecological state, the use of land resources, the anthropogenic load on rural areas, the development of degradation processes and the development of measures to reduce them. Thus, the definition of the natural value of agricultural land on the example of the region of Apulia, Italy is considered in the scientific work of F. Bozzo, V. Fucilli, A. Petrontino, S. Girone (Bozzo et.al., 2019).

Prospects for the development of agrarian reforms in the field of land relations in Ukraine are considered in the scientific work of M. Bogira (Bogira et.al., 2019).

$\mathrm{H}$. Hansson studied the attitude of farmers to environmental changes related to agricultural production using the example of the restoration of the wetlands of Lake Hurnborgashen in Sweden (Hansson, Kokko, 2018).

The issues of re-profiling of agricultural lands to combat climate change were considered by $\mathrm{H}$. Vinge (Vinge, 2000).

Bonn University professor Joachim von Braun notes that land degradation is a serious economic problem in the Baltic region, and further inaction will lead to serious losses (Von Braun, Mirzabaev, 2018).

The scientific work of Bai Z. G., Dent D. L., Olsson L., Schaepman M. E. (Bai et.al., 2008) reflects the results of the analysis of 23-year studies of degrading areas around the world, identifies the most affected regions and evaluates the impact of individual factors on the current situation. 
In A. Karklins, a researcher at the Latvia University of Agriculture, examines in his work the state of the soil in Latvia and highlights the factors that affect soil productivity and its vulnerability to pollution in the long term (Karklins, 2000).

To ensure sustainable development of agricultural production, rational use of land resources, it is necessary to analyze the dynamics of changes in their area, zoning of the territory according to agroecological factors and the introduction of measures to reduce environmental stress.

The basis of project proposals for the organization of rational use of land resources are regional schemes for the use and protection of land resources; schemes of land management of administrative-territorial and territorial units, territories of special state regulation; projects of inter-farm and intra-farm land management; working projects for land reclamation, land contours, soil protection from erosion and other harmful effects, preservation and enhancement of soil fertility and other useful properties of land (Кодекс Республики Беларусь..., 2008).

\section{Methodology of research and materials}

In the scientific research, dialectical, abstract-logical and monographic methods were used, as well as the method of induction, deduction, analogy, analysis, synthesis, correlation-regression analysis and others. The basis of the scientific search was the existing scientific developments in the field of land use and land management of domestic and foreign scientists and the experience of using land in the agroindustrial complex of the republic.

For scientific research, land registration data, information on the quantitative and qualitative state of lands, regulatory and legislative acts in the field of land use and protection, as well as scientific and reference literature, etc. were used.

The calculation of the coefficient of ecological stability of the territory was made according to the formula (Колмыков, 2013):

$$
K_{e . s t .}=\frac{\sum_{i=1}^{n} k_{i} P_{i}}{\sum_{i=1}^{n} P_{i}} k_{i},
$$

$k_{i}$ - coefficient of ecological stability of landsof the $i$-th type;

$P_{i}-$ land areaof the $i$-th type, hectare;

$k_{p}$ - coefficient of morphological stability of the relief.

In accordance with the proposal of S.N. Volkov's classification (Волков и др., 1992), depending on the obtained values of the coefficient of ecological stability $\left(\mathrm{K}_{\mathrm{ests}}\right)$, the studied territories can be attributed to:

- ecologically unstable territories, if $\mathrm{K}_{\mathrm{e} . \mathrm{st} .}$ less than 0.33 ;

- unstable stable territories, if $\mathrm{K}_{\mathrm{e} . \mathrm{st} .}$ is in the range from 0.34 to 0.50 ;

- moderately stable territories, if $\mathrm{K}_{\text {e.st. }}$ is in the range from 0.51 to 0.66 ;

- ecologically stable territories, if $\mathrm{K}_{\text {e.st. }}$ more than 0.67 .

The coefficient of anthropogenic load on the territory is determined by the formula (Волков, 2001):

$$
K_{A L}=\frac{\sum_{i=1}^{n} B_{i} P_{i}}{\sum_{i=1}^{n} P_{i}}
$$

$5_{i}$ - score corresponding to an area with a certain anthropogenic load;

$P_{i}$ - area of the i-th type of land with the corresponding anthropogenic load, hectare.

According to the classification proposed by S.N. Volkov (Волков, 2001), the degree of anthropogenic load and the corresponding scores are adapted to the species composition of the lands of the Republic of Belarus and are presented in table 1. 
The degree of anthropogenic pressure on the territory

\begin{tabular}{|l|c|l|}
\hline \multicolumn{1}{|c|}{ Anthropogenic load } & Score & \multicolumn{1}{c|}{$\begin{array}{c}\text { Lands corresponding to the degree of anthropogenic load } \\
\text { and assessment score }\end{array}$} \\
\hline High & 5 & $\begin{array}{l}\text { Land under roads and other transport communications, public } \\
\text { land, building land, disturbed land }\end{array}$ \\
\hline Significant & 4 & Arable land and land under permanent crops \\
\hline Average & 3 & Meadow lands, fallow lands \\
\hline Insignificant & 2 & $\begin{array}{l}\text { Forest lands, lands under swamps and under water bodies, as } \\
\text { well as lands under trees and shrubs }\end{array}$ \\
\hline Low & 1 & Unused lands, other lands \\
\hline
\end{tabular}

\section{Discussions and results}

According to the main document regulating land relations in the republic, the Land Code of the Republic of Belarus, the concept of land resources is defined as land, land plots that are used or can be used in economic or other activities (Кодекс Республики Беларусь..., 2008). Thus, land resources are a part of the land fund that is used or can be used in the national economy.

The current state and structure of land resources in the republic are determined by natural and climatic conditions, the results of economic activities, as well as economic and social features of the development of territories and measures aimed at preserving land.

In accordance with the legislation on the protection and use of land, data on the composition, structure and distribution of land resources are contained in the Register of Land Resources of the Republic of Belarus (Реестр земельных ресурсов..., 2020). It follows from this document that as of January 1, 2020 , the total land area of the republic amounted to 20760 thousand hectares. The entire land fund of the republic is divided into seven categories, its composition and structure are shown in figure 1.

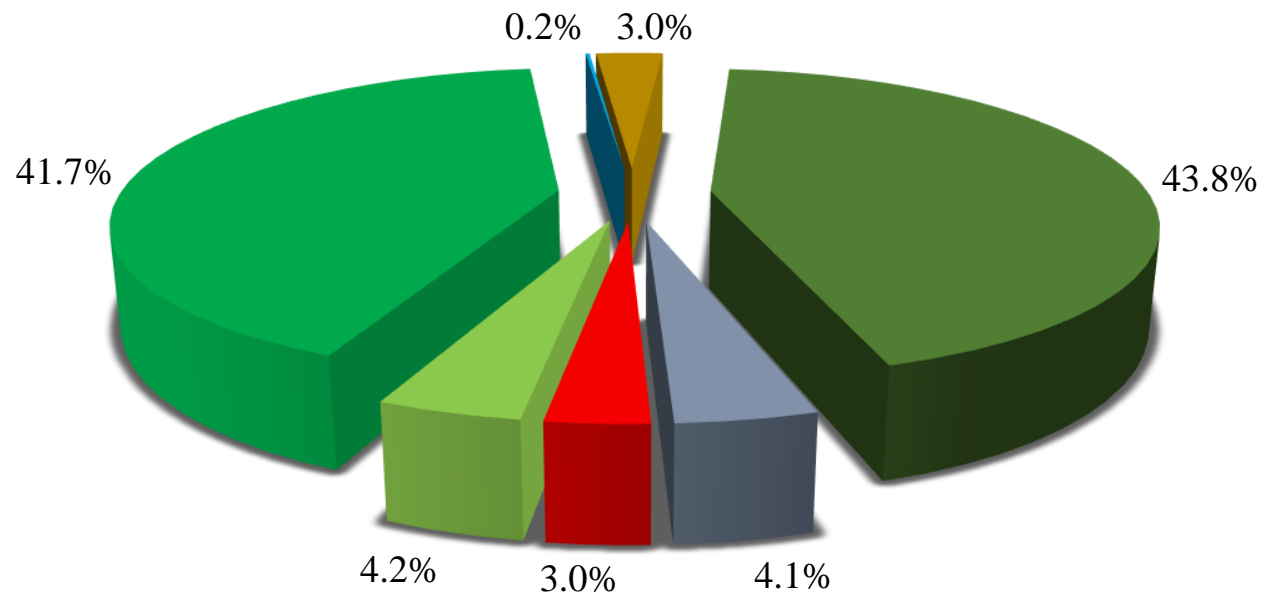

\footnotetext{
agricultural land

- lands of settlements, horticultural associations, dacha cooperatives

lands for industry, transport, communications, energy, defense and other purposes

lands for nature conservation, health improvement, recreational, historical and cultural purposes

- forest lands

- water fund lands

stock lands
}

Fig. 1.Composition and structure of the land fund of the republic in the context of land categories as of 01.01 .2020

The distribution by land categories is as follows: agricultural land occupies 9103.0 thousand hectares or $43.8 \%$ of the total area of the republic; lands of settlements, horticultural associations, dacha cooperatives - 849.0 thousand hectares, or $4.1 \%$; land for industry, transport, communications, energy, defense and other purposes - 622.2 thousand hectares, or 3.0\%; land for nature conservation, health- 
improving, recreational, historical and cultural purposes - 868.7 thousand hectares, or $4.2 \%$; forest land - 8656.4 thousand hectares, or $41.7 \%$; water fund lands - 37.3 thousand hectares, or $0.2 \%$; reserve lands - 623.4 thousand hectares, or $3.0 \%$.

In addition to the division into land categories, the lands of the Republic of Belarus are divided into fourteen types (fig. 2).

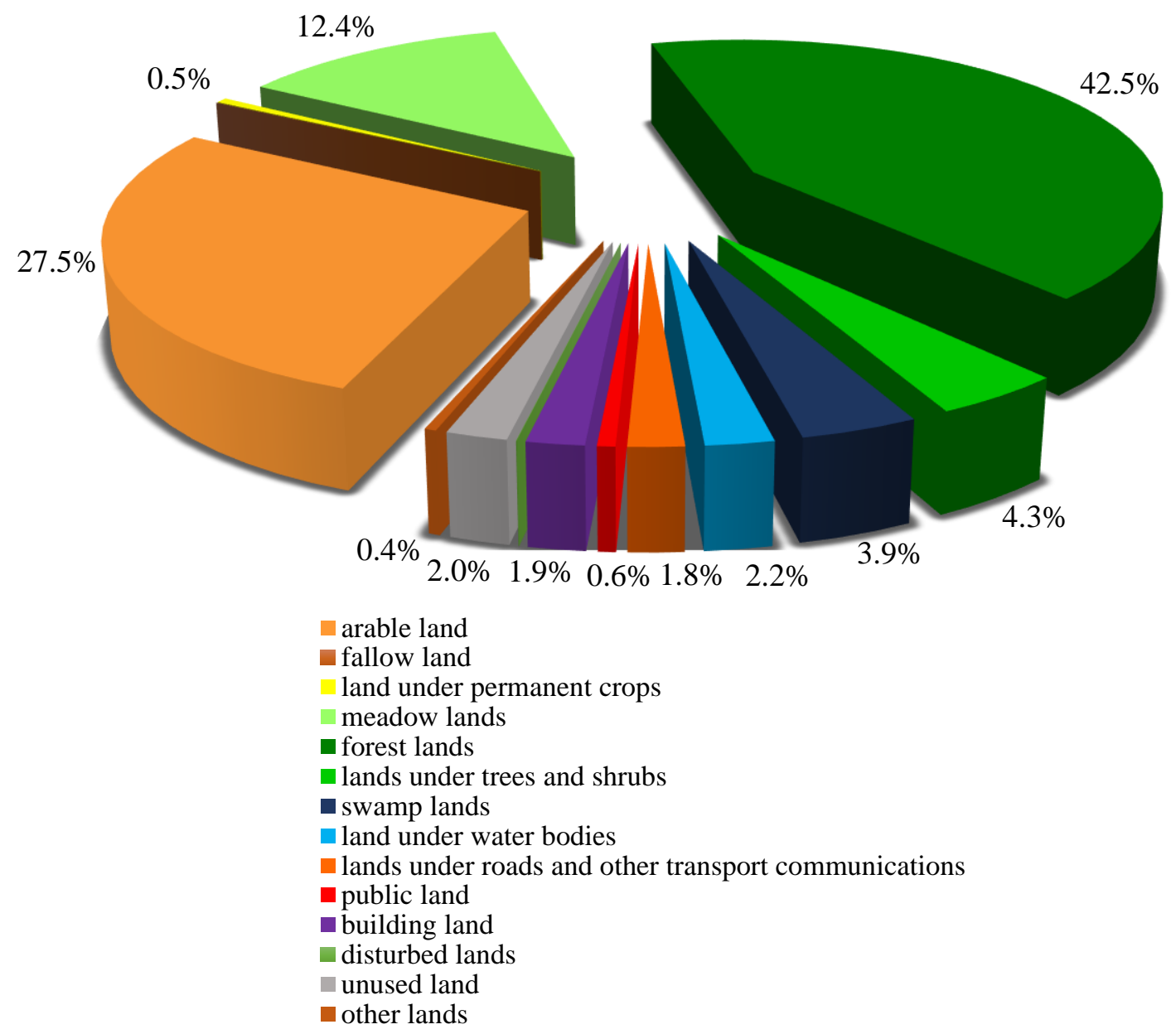

Fig. 2. Composition and structure of the land fund of the republic in the context of land types as of 01.01 .2020

The distribution by type of land is as follows: arable land makes up 27.52\% of the total area of the republic, or 5713.1 thousand hectares; fallow lands - $0.06 \%$, or 3.5 thousand hectares; land under permanent crops $-0.51 \%$ or 106.5 thousand hectares; meadow lands $-12.37 \%$ or 2567.5 thousand hectares; forest lands $-42.45 \%$, or 8813.6 thousand hectares; land under trees and shrubs $-4.32 \%$, or 897.8 thousand hectares; land under swamps $-3.86 \%$, or 801.0 thousand hectares; land under water bodies $-2.23 \%$, or 463.5 thousand hectares;land under roads and other transport communications $1.83 \%$, or 379.7 thousand hectares; common land $-0.59 \%$, or 121.9 thousand hectares; building land $1.89 \%$, or 392.9 thousand hectares; disturbed lands - $0.02 \%$, or 3.6 thousand hectares; unused land $2.00 \%$, or 415.5 thousand hectares; other lands $-0.38 \%$, or 79.9 thousand hectares. Thus, the basis of the land resources used in the agro-industrial complex of the republic is arable and meadow lands.

The distribution of land in the Republic of Belarus by forms of land ownership is as follows: the share of state ownership is $99.63 \%$, or 20683.6 thousand hectares, the share of private property is only $0.37 \%$, or 76.4 thousand hectares.

The distribution according to the types of land rights is as follows: 713.6 thousand hectares, or $3.44 \%$ of all lands of the republic, are in inherited possession for life; in permanent use - 18817.9 thousand hectares, or 90.64\%; in temporary use - 257.1 thousand hectares, or $1.24 \%$; rented - 283.2 thousand hectares, or $1.36 \%$ and privately owned -76.4 thousand hectares, or $0.37 \%$. 
The land fund of the republic is distributed among land users as follows: 8854.4 thousand hectares of land are assigned to agricultural organizations, or $42.7 \%$; for peasant (farm) households - 248.6 thousand hectares, or $1.2 \% ; 849.0$ thousand hectares, or $4.1 \%$, were allocated for the needs of citizens; industrial organizations occupy 60.7 thousand hectares, or $0.3 \%$; railway transport organizations use 48.7 thousand hectares or $0.2 \%$; motor transport organizations - 159.8 thousand hectares, or $0.8 \% ; 154.2$ thousand hectares, or $0.7 \%$, are assigned to the organizations of the Armed Forces of the Republic of Belarus; communications, energy, construction, trade, education and healthcare organizations use 198.8 thousand hectares, or $1.0 \%$; environmental, health, recreational, historical and cultural organizations occupy 868.7 thousand hectares, or $4.2 \%$; 8656.4 thousand hectares, or $41.7 \%$, are assigned to forestry;organizations operating and maintaining hydraulic and other water management structures use 37.3 thousand hectares, or $0.2 \%$; land plots not provided to land users, and common land not classified as land of other categories of land users, amount to 623.4 thousand hectares, or $3.0 \%$.

The assessment of the qualitative state of land resources of the Republic of Belarus was carried out using the data (points of the cadastral assessment and the point of soil fertility) of the first and second rounds of the cadastral assessment of agricultural lands by administrative regions and the republic (table 2).

Table 2

Indicators of cadastral valuation of agricultural lands of the Republic of Belarus and its regions

\begin{tabular}{|l|c|c|c|c|}
\hline \multirow{2}{*}{ Name } & \multicolumn{2}{c|}{$\begin{array}{c}\text { Total score of the cadastral } \\
\text { assessment }\end{array}$} & \multicolumn{2}{c|}{ Scoreofsoilfertility } \\
\cline { 2 - 5 } & firsttour & secondtour & firsttour & secondtour \\
\hline Brestregion & 29.7 & 30.6 & 29.5 & 30.2 \\
\hline Vitebskregion & 24.8 & 23.3 & 25.7 & 25.8 \\
\hline Gomelregion & 27.8 & 26.9 & 27.6 & 27.3 \\
\hline Grodnoregion & 31.7 & 32.3 & 31.7 & 32.9 \\
\hline MinskRegion & 30.7 & 31.0 & 30.3 & 31.3 \\
\hline Mogilevregion & 29.5 & 27.7 & 28.9 & 28.8 \\
\hline RepublicofBelarus & 29.0 & 29.0 & 28.9 & 29.0 \\
\hline
\end{tabular}

Analysis of the results of the cadastral assessment of land and soil fertility (table 2) showed that the maximum scores were recorded in the Grodno region and are 31.7 and 32.9, respectively, and the minimum are in the Vitebsk region - 25.7 and 25.8. Despite the constancy of the value of the score of the cadastral assessment of land in the Republic of Belarus according to the results of the first and second rounds - 29.0, there is a slight decrease in the Vitebsk region (-1.0), Gomel (-1.2) and Mogilev regions $(-1.8)$, and in Brest, Grodno and Minsk regions have some growth, respectively - $(+0.8)$ and $(+0.4)$ points. There is also an increase in the score of land fertility in the Brest region - $(+0.7)$, Grodno - $(+1.2)$, Minsk region - (+1.0). In other regions, the change in the fertility score is insignificant. In the republic as a whole, the fertility score, according to the second round, was 29.0.

It should be noted that the increase in the values of the indicators under consideration is primarily due to the use of fertilizers and plant protection products, as well as the use of modern adaptive agricultural production technologies. The decrease in the score of the cadastral valuation of land is associated with the transfer of highly productive agricultural land for non-agricultural purposes, land degradation, and the emergence of spatial and territorial deficiencies.

For the ecological assessment of the territory of the Republic of Belarus in the context of administrative regions, the coefficients of the ecological stability of the territory and the anthropogenic load on the territory are determined.

After calculating the coefficient of ecological stability of the territory in accordance with the adopted classification (Волков и др., 1992) and depending on the obtained values of the coefficient of ecological stability $\left(\mathrm{K}_{\mathrm{ests}}\right)$, it can be stated that, in general, the territory of the Republic of Belarus belongs to medium stable territories, since $\mathrm{K}_{\text {e.st. equals }} 0.63$, but if we consider this indicator in the context of regions, then the following is established: the territories of Brest region $\left(\mathrm{K}_{\mathrm{e} . \mathrm{st}}=0.63\right)$, Grodno region $\left(\mathrm{K}_{\text {e.st. }}=0.57\right)$, Minsk region $\left(\mathrm{K}_{\text {e.st. }}=0.58\right)$ belong to the average stable and Mogilev regions $\left(\mathrm{K}_{\text {e.st. }}=\right.$ $0.63)$; the group of ecologically stable territories includes Vitebsk $\left(K_{\text {e.st. }}=0.69\right)$ and Gomel region $\left(K_{\text {e.st. }}=\right.$ 0.68 ).

As a result of the study, the following values of the coefficient of anthropogenic load on the territory were obtained: Brest region $K_{A L}=2.78$, Vitebskregion $-K_{A L}=2.67$, Gomel region $-K_{A L}=2.64$, Grodno region $-K_{A L}=2.93$, Minsk region $-K_{A L}=2.93$ and Mogilev region $-K_{A L}=2.83$, in the republic as a 
whole $K_{A L}=2.79$. According to the classification proposed by Professor Volkov (Волков, 2001), according to the degree of anthropogenic load, the territory of the Republic of Belarus as a whole and its administrative regions in particular belongs to territories with a relatively low anthropogenic load.

To analyze the change in land areas, based on the materials of the state land cadastre over the past ten years, the three largest types of land in terms of area were selected, which are the main land resources of the republic - arable, meadow and forest, moreover, these lands have the greatest impact on the ecological stability of the territory. The dynamics of the areas of these types of land is presented in table 3.

Table 3

Dynamics of the distribution of arable, meadow and forest lands in the context of the administrative regions of the Republic of Belarus, thousand hectares

\begin{tabular}{|c|c|c|c|c|c|c|c|}
\hline Years & $\begin{array}{c}\text { Republic } \\
\text { of Belarus }\end{array}$ & $\begin{array}{l}\text { Brest } \\
\text { region }\end{array}$ & $\begin{array}{l}\text { Vitebsk } \\
\text { region }\end{array}$ & $\begin{array}{l}\text { Gomel } \\
\text { region }\end{array}$ & $\begin{array}{c}\text { Grodno } \\
\text { region }\end{array}$ & $\begin{array}{l}\text { Minsk } \\
\text { Region } \\
\end{array}$ & $\begin{array}{c}\text { Mogilev } \\
\text { region }\end{array}$ \\
\hline \multicolumn{8}{|c|}{ Arable land } \\
\hline 2011 & 5510.5 & 818.0 & 910.7 & 812.4 & 846.0 & 1261.1 & 860.2 \\
\hline 2012 & 5506.4 & 817.9 & 907.5 & 814.6 & 844.2 & 1259.4 & 860.8 \\
\hline 2013 & 5521.6 & 816.9 & 919.7 & 818.9 & 844.4 & 1259.6 & 860.2 \\
\hline 2014 & 5559.7 & 820.4 & 962.1 & 820.2 & 841.6 & 1251.7 & 861.8 \\
\hline 2015 & 5662.1 & 828.4 & 961.1 & 863.8 & 840.9 & 1314.5 & 851.5 \\
\hline 2016 & 5677.4 & 832.3 & 956.4 & 881.3 & 843.2 & 1311.1 & 851.2 \\
\hline 2017 & 5683.8 & 834.4 & 914.4 & 914.2 & 844.2 & 1314.1 & 860.6 \\
\hline 2018 & 5727.3 & 835.2 & 913.0 & 916.2 & 845.1 & 1349.1 & 866.9 \\
\hline 2019 & 5712.3 & 835.0 & 906.7 & 911.5 & 843.8 & 1348.0 & 865.5 \\
\hline 2020 & 5713.1 & 842.9 & 907.4 & 909.5 & 841.8 & 1346.6 & 863.0 \\
\hline \multicolumn{8}{|c|}{ Meadow lands } \\
\hline 2011 & 3240.6 & 590.5 & 639.7 & 552.4 & 395.2 & 570.5 & 491.9 \\
\hline 2012 & 3223.7 & 588.2 & 637.0 & 549.2 & 388.6 & 568.4 & 491.9 \\
\hline 2013 & 3154.0 & 584.9 & 597.8 & 526.2 & 386.2 & 566.3 & 492.2 \\
\hline 2014 & 3032.6 & 579.0 & 523.1 & 517.6 & 385.9 & 564.0 & 462.6 \\
\hline 2015 & 2844.0 & 566.4 & 512.0 & 465.4 & 380.4 & 499.1 & 420.3 \\
\hline 2016 & 2783.6 & 554.1 & 501.6 & 433.6 & 374.8 & 500.0 & 419.1 \\
\hline 2017 & 2737.6 & 534.8 & 536.9 & 394.5 & 371.6 & 498.4 & 401.0 \\
\hline 2018 & 2653.1 & 533.9 & 526.0 & 389.0 & 357.6 & 460.6 & 385.6 \\
\hline 2019 & 2629.6 & 534.0 & 513.9 & 383.2 & 358.7 & 461.0 & 378.4 \\
\hline 2020 & 2567.5 & 504.5 & 502.6 & 372.5 & 357.5 & 461.4 & 368.6 \\
\hline \multicolumn{8}{|c|}{ Forest land } \\
\hline 2011 & 8566.7 & 1223.6 & 1666.8 & 2014.4 & 915.2 & 1604.6 & 1139.4 \\
\hline 2012 & 8584.7 & 1230.7 & 1668.6 & 2015.6 & 918.9 & 1607.7 & 1140.5 \\
\hline 2013 & 8588.5 & 1233.8 & 1668.5 & 2018.6 & 919.8 & 1603.3 & 1138.7 \\
\hline 2014 & 8630.7 & 1233.6 & 1671.3 & 2023.5 & 922.7 & 1600.8 & 1173.0 \\
\hline 2015 & 8652.6 & 1235.8 & 1679.8 & 2029.9 & 922.8 & 1600.0 & 1178.5 \\
\hline 2016 & 8742.1 & 1244.4 & 1719.6 & 2054.1 & 922.4 & 1604.9 & 1190.9 \\
\hline 2017 & 8769.4 & 1248.6 & 1723.8 & 2069.3 & 923.7 & 1605.6 & 1192.6 \\
\hline 2018 & 8773.5 & 1248.9 & 1718.5 & 2071.2 & 928.4 & 1607.4 & 1193.4 \\
\hline 2019 & 8791.0 & 1249.5 & 1722.6 & 2071.0 & 934.5 & 1607.5 & 1200.2 \\
\hline 2020 & 8813.6 & 1260.7 & 1724.4 & 2072.4 & 939.6 & 1607.8 & 1202.8 \\
\hline
\end{tabular}

According to the data in table 3, it is established that in the republic and in separate regions there is a tendency for a significant reduction in the area of meadow lands, in a ten-year period their area has decreased by $26.2 \%$, or 673.1 thousand hectares. The area of arable and forest lands for the same period increased by 3.6 and $2.8 \%$, or 202.6 and 246.9 thousand hectares, respectively.

The study of the dynamics of areas was carried out using correlation-regression analysis, as a result, functions were selected that most accurately describe the ongoing changes in the selected types of land (table 4). 
Forecast of arable, meadow and forest land areas for 2023.

\begin{tabular}{|c|c|c|c|}
\hline \multirow{2}{*}{ Name } & \multirow{2}{*}{$\begin{array}{l}\text { Forecast } \\
\text { Function }\end{array}$} & \multicolumn{2}{|c|}{$\begin{array}{l}\text { Area, thousand } \\
\text { hectares }\end{array}$} \\
\hline & & 2020 & 2023 \\
\hline \multicolumn{4}{|l|}{ Arable land } \\
\hline Republic of Belarus & $y=-2.115 x^{2}+51.63 x+5424.0$ & 5713.1 & 5737.8 \\
\hline Brest region & $y=0.045 x^{2}+2.420 x+813.0$ & 842.9 & 852.1 \\
\hline Vitebsk region & $y=-2.254 x^{2}+23.48 x+883.5$ & 907.4 & 807.8 \\
\hline Gomel region & $y=-0.511 x^{2}+19.8 x+777.0$ & 909.5 & 948.0 \\
\hline Grodno region & $y=0.073 x^{2}-0.976 x+846.0$ & 841.8 & 845.6 \\
\hline Minsk region & $\mathrm{y}=0.198 \mathrm{x}^{2}+10.06 \mathrm{x}+1238.0$ & 1346.6 & 1402.2 \\
\hline Mogilev region & $\mathrm{y}=0.328 \mathrm{x}^{2}-3.081 \mathrm{x}+864.4$ & 863.0 & 879.8 \\
\hline \multicolumn{4}{|l|}{ Meadow lands } \\
\hline Republic of Belarus & $y=3.511 x^{2}-121.4 x+3419.0$ & 2567.5 & 2434.2 \\
\hline Brest region & $y=-0.484 x^{2}-4.088 x+598.1$ & 504.5 & 463.2 \\
\hline Vitebsk region & $y=3.020 x^{2}-47.91 x+696.3$ & 502.6 & 583.9 \\
\hline Gomel region & $y=0.631 x^{2}-30.38 x+601.1$ & 372.5 & 312.8 \\
\hline Grodno region & $y=-0.099 x^{2}-3.389 x+398.1$ & 357.5 & 337.3 \\
\hline Minsk region & $y=0.150 x^{2}-16.55 x+600.2$ & 461.4 & 410.4 \\
\hline Mogilev region & $y=0.293 x^{2}-19.12 x+525.0$ & 368.6 & 326.0 \\
\hline \multicolumn{4}{|l|}{ Forest land } \\
\hline Republic of Belarus & $y=-0.408 x^{2}+35.38 x+8512.0$ & 8813.6 & 8903.0 \\
\hline Brest region & $\mathrm{y}=0.061 \mathrm{x}^{2}+2.932 \mathrm{x}+1222.0$ & 1260.7 & 1270.4 \\
\hline Vitebsk region & $y=-0.152 x^{2}+9.822 x+1648.0$ & 1724.4 & 1750.0 \\
\hline Gomel region & $y=-0.038 x^{2}+8.512 x+1998.0$ & 2072.4 & 2092.2 \\
\hline Grodno region & $y=0.255 x^{2}-0.539 x+917.9$ & 939.6 & 954.0 \\
\hline Minsk region & $y=0.209 x^{2}-1.896 x+1607.0$ & 1607.8 & 1617.7 \\
\hline Mogilev region & $y=-0.651 x^{2}+15.24 x+1116.0$ & 1202.8 & 1204.1 \\
\hline
\end{tabular}

A retrospective analysis of the dynamics of the use of arable, meadow and forest lands and a forecast for a three-year perspective showed that, while maintaining the current trends in their change, the area of arable and forest lands in the republic by 2023 will increase by 24.7 and 89.4 thousand hectares, or 0.43 and $1.01 \%$ in comparison with 2020 and will amount to 5737.8 and 8903.0 thousand hectares, respectively. The area of the meadow land will be reduced by 133.3 thousand hectares or $5.19 \%$ and will amount to 2434.2 thousand hectares.

According to the research carried out, it was found that in order to increase the efficiency of the use of land resources in agricultural organizations, it is advisable to carry out the following measures:

- to introduce the implementation of agroecological zoning of the territory of land use of agricultural organizations with the establishment of a regime for the use of land in the allocated zones;

- carry out the transformation of land, taking into account its environmental acceptability and economic feasibility in order to increase the area of agricultural land;

- to optimize the size of land use of agricultural organizations;

- to improve the specialization of production of agricultural enterprises based on the availability of land, material and labor resources, as well as the social need for agricultural products and other factors;

- eliminate territorial disadvantages of land use;

- to establish a rational ratio of lands;

- introduce adaptive crop rotations;

- to ensure the rational placement of agricultural crops in ecological and technological working areas;

- to reduce soil compaction by machine-tractor units;

- to bring the crops of labor-intensive, load-intensive and machine-intensive agricultural crops closer to economic centers and improved roads;

- to place crops of agricultural crops cultivated by machine-intensive technologies in areas with maximum rut length, minimum slopes and soil resistivity. 
In the process of land management of administrative-territorial and territorial units, introduce the following measures to maintain the environmental stability of their territory:

- transfer of unproductive land plots for non-agricultural purposes,

- reclamation of disturbed lands,

- a decrease in the intensity of land use (the introduction of soil-protective crop rotations, the creation of perennial meadow lands, etc.),

- allocation of land for ecological corridors;

- arrangement of zones with environmental protection regime;

- intensification of agricultural production within ecologically acceptable limits;

- ecologically acceptable elimination of small contour;

- improvement of the land reclamation state;

- maintaining the ecological well-being of the territory;

- to introduce the principles and methods of organic farming in agricultural organizations to restore the natural fertility of the land and reduce the anthropogenic impact on the land;

- to introduce the practice of state support and encouragement of agricultural producers for ensuring their effective use of land and improving their quality condition.

\section{Conclusions and proposals}

As a result of the performed scientific research, the following conclusions can be drawn:

1. All lands of the Republic of Belarus are subdivided into 7 categories and 14 types. The largest area is occupied by agricultural land - 9103.0 thousand hectares, or $43.8 \%$ of the total area of the republic, and the smallest - land of water resources -37.3 thousand hectares, or $0.2 \%$. In accordance with the species composition of the republic's lands, the largest area is occupied by forest lands - $42.45 \%$, or 8813.6 thousand hectares, and the smallest - disturbed lands $-0.02 \%$, or 3.6 thousand hectares.

2. The state property is 20683.6 thousand hectares, or $99.63 \%$ of the republic's land, in private ownership - 76.4 thousand hectares, or $0.37 \%$.

3. Analysis of the results of the first and second rounds of cadastral valuation of land and soil fertility showed that despite the constancy of the value of the cadastral valuation of land in the Republic of Belarus - 29.0, there is a slight decrease in the Vitebsk region (-1.0), Gomel (-1.2) and Mogilev regions $(-1.8)$, and in Brest, Grodno and Minsk regions there is some growth, respectively - $(+0.8)$ and $(+0.4)$ points. The land fertility score increased in the Brest region - (+0.7), Grodno - $(+1.2)$, Minsk region $(+1.0)$. In other areas, the change in the fertility score is insignificant. In the republic as a whole, the fertility score, according to the second round, was 29.0.

4. The existing organization of the lands of the Republic of Belarus as a whole allows its territory to be ecologically related to medium stable territories, the coefficient of ecological stability is 0.63 ;

5. Analysis of the anthropogenic load on the territory of the republic makes it possible to classify it as a balanced territory in terms of land composition with a relatively low anthropogenic load. the anthropogenic load factor is 2.79 ;

6. Retrospective analysis of the dynamics of the areas of arable, meadow and forest lands of the republic and regions for the period from 2011 to 2020 . revealed a tendency towards a reduction in the area of meadow lands and an increase in the area of arable and forest land relative to the initial year (2011).

7. The forecast of the areas of productive land until 2023 showed that the area of arable and forest land in the republic will increase by 24.7 and 89.4 thousand hectares, or 0.43 and $1.01 \%$ in relation to 2020 and will amount to 5737.8 and 8903.0 thousand hectares, respectively, and meadow land will be reduced by 133.3 thousand hectares, or $5.19 \%$ and will amount to 2434.2 thousand hectares.

8. To increase the efficiency of the use of land resources in agricultural organizations and maintain the ecological stability of their territory, it is advisable to carry out the measures given in the scientific work.

\section{References}

1. Bai Z. G., Dent D. L., Olsson L., Schaepman M. E. (2008) Proxy global assessment of land degradation, Soil use and management, Vol. 24, no. 3, p. 223-234.

2. Bogira M., Sokhnych A., Soliarchuk Y. (2019) Prospects Of Agrarian Formations Development At The Stage Of Land Relations Transformations In Ukraine, Scientific Papers: Management, Economic Engineering in Agriculture \& Rural Development, Vol. 19, p. 37-43.

3. Bozzo F., Fucilli V., Petrontino A., Girone S. (2019). Identification of High Nature Value Farmland: a methodological proposal. Italian Review of Agricultural Economics, Vol. 74(3), p. 29-41.

4. Hansson H., Kokko S. (2018) Farmers' mental models of change and implications for farm renewal - A case of restoration of a wetland in Sweden, Journal of Rural Studies, Vol. 60, p. 141-151. 
5. Karklins A. (2000) Soil degradation status and data availability in Latvia. In: Batjes N and Bridges E, Implementation of a Soil Degradation and Vulnerability database for Central and Eastern Europe, FAO and ISRIC, Rome, Italy.

6. Vinge H. (2018) Farmland conversion to fight climate change? Resource hierarchies, discursive power and ulterior motives in land use politics, Journal of Rural Studies, 2018, Vol. 64, p.20 - 27.

7. Von Braun J., Mirzabaev A. (2016), Land Use Change and Economics of Land Degradation in the Baltic Region, Baltijskij region, Vol. 8, no. 3, p. $45-60$.

8. Волков С.Н. (2001) Землеустройство: в 9-ти т. Т. 2: Землеустроительное проектирование. Внутрихозяйственное землеустройство (Land management: in nine volumes Volume 2: Land management design. On-farm land management).«Колос», Москва, 648 с.(in Russian).

9. Волков С.Н., Хлыстун В.Н., Улюкаев В.Х. (1992) Основы землевладения и землепользования (Fundamentals of land tenure and land use). «Колос», Москва, 144 с.(in Russian).

10. Кодекс Республики Беларусь о земле (Land Code of the Republic of Belarus) от 23.07.2008 № 425-3: ред. от 18.07.2016 // Нац. реестр правовых актов Респ. Беларусь. 30 июля, 2008, № 2/1522 (in Russian).

11. Колмыков А.В. (2013) Землеустроительное обеспечение организации рационального использования земель сельскохозяйственного назначения (Land management support for the organization of rational use of agricultural land). УО БГСХА, Горки, 337 с. (in Russian).

12. Колмыков А.В., Авдеев А.Н. (2019) Зонирование территории Минской области для целей землеустройства (Zoning of the territory of the Minsk region for land management purposes). Вестник БГСХА. Научно-методический журнал, № 1,Горки: УО БГСХА, с.143 - 148 (in Russian).

13. Реестр земельных ресурсов Республики Беларусь (Register of land resources of the Republic of Belarus) ( http://www.http://gki.gov.by/ru/activity_branches-land-reestr) (in Russian).

\section{Information about authors:}

Andrey, Kolmykov, Doctor of Economic Sciences, docent, First Vice-Rector, Belarusian State Agricultural Academy.213407, Belarus, Mogilev region., Horki, st.Michurina 5, +375 (29) 692-17-66, kolmykov@ tut.by. Land management, land optimization, economics of land management.

Alexey, Avdeev, Assistant of the Department of Land Management, Belarusian State Agricultural Academy.213407, Belarus, Mogilev region., Horki, st.Mandrikova 4, +375 (25) 756-26-49, lex_avdeev@bk.ru. Land management, land optimization, economics of land management. 